\title{
単杭の静的押込み試験法に関する考察 \\ CONSIDERATIONS ON METHOD FOR AXIAL STATIC COMPRESSIVE LOAD TEST OF SINGLE PILES
}

\author{
国府田 誠*1, 山下利夫*2, 斎藤 英明*3, 田村.昌仁*4 \\ 佐藤秀人*5, 笹沼 美和*6, 刑部 徹*7 \\ Makoto KOUDA, Toshio YAMASHITA, Hideaki SAITO, Masahito TAMURA, \\ Hideto SATO, Miwa SASANUMA and Toru OSAKABE
}

\begin{abstract}
In the static axial compressive load tests of a single pile, various methods are in existence, i.e.; the direct loading method, the method using reaction piles, the method using masses as loading reaction, the pile-toe loading method and so on. However, in these methods, influence of the loading reaction has not been compared and discussed enough. We carried out various load tests of model piles in order to examine the above.problems. From these results, we could understand that the initial rigidities of compressive loads are evaluated larger and the ultimate bearing capacities are evaluated smaller in the cases of using reaction devices.
\end{abstract}

Keynords: Single Pile, Axial Compressive Loading Test, LoadReaction, Pile Skin Friction, Pile-toe Load 単杭, 押込々試験, 載荷反力, 杭周面摩擦力, 先端荷重

\section{1. 序論}

杭の支持力〜沈下関倸は載荷試験によって求めるのが原則とされ ている。また, 載荷試験は実杭を用い, より実状に近い実荷重下で 実施することが望ましい。しかしながら，杭の発達により支持力が 増大している現状において, 実杭を用い, 実荷重を直接的に載荷す る試験の実施が困難となっている。そのため載荷反力を用いた静的 押込み試験の適用が余儀なくされている。本論文は各種静的押込み 試験法について模型試験によって考察するものである。

（1）押込み試験法の概要

図，1に，主な静的押込み試験法について，その載荷方式と荷重伝 達線の模式図を示す。なお, 本荷重伝達線図は, 載荷によって新た に発生する応力において, 絶対主态力が最大となる主応力線を結ん だものと定義し，次の 3 原則を設定することにより，推測よって描 いたものである。

i ）荷重〜反力機構において,荷重の全ては反力体に伝達される。

ii）荷重伝達線は荷重点から反力点に向かい，途切れたり，分岐
したりしない。

ii）同一荷重源から発生する荷重伝達線は交わらない。

ただし， i ）は力の釣合いの原理・原則によるものであり， ii ）, iii）は磁石の正極および負極が, 杭の載荷試験法の載荷および反力 に対応するものとし，磁力線の原則を参考にしたものである。

図 1 において, 実載荷方式（a）は，前述したように反力の影響 の無い理想的な試験法であり, 荷重伝達線は広がりをもって地中哚 くに伝達する。実重量反力方式（b）は，一般には実荷重方式と呼 ばれているものであり ${ }^{1)}$ ，コンクリート塊や鋼材などのような重量 物を載せた架構を載荷反力とするものである。本論文では実載荷方 式（a）との混乱を避けるため, 実重量反力方式と呼ぶことにした。 なお，載荷が始まると，この方式の架楧の支点反力は載荷に等しい， 分だけ減少することになる。載荷前の架構支点から地中に伝達され る応力 $(b-A)$ を無視すると, 載荷によって新たに発生する荷重伝 達線は，上記原則に従い，杭周面および杭先端から架構の支点に向 かう形状となり，あたかも引抜き抵抗体が支点の下に存在している

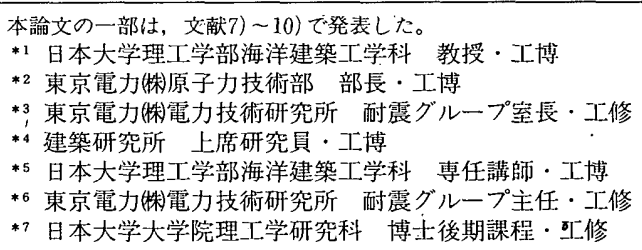

Prof., Dept. of Oceanic Architecture \& Eng., Nihon Univ., Dr. Eng.

G.M. Nuclear Power Engineering Dept., TEPCO, Dr. Eng.

G.M., Power Engineering R\&D Center, TEPCO, M. Eng.

Chief Research Engineer, Building Research Institute, Dr. Eng.

Assist. Prof., Dept. of Oceanic Architecture \& Eng., Nihon Univ., Ph. D.

Power Engineering R\&D Center, TEPCO, M. Eng.

Graduate Student, Graduate School of Science \& Tech., Nihon Univ., M. Eng. 
かのような形状になることが推測される（b-B)。これは，この方 式が実荷重を直接的に作用させる方式ではなく，実重量を反力とす， る方式であり，載荷反力の影響を受ける試験法であることを意味し ている。反力杭方式 (c) は, 試験杭近傍に設置された杭（反力杭） を載荷反力とするものであり，杭頭押込み試験法の基準的な存在と なっている。この方式の荷重伝達線は，上記原則に従って杭周面お よび杭先端から反力杭に向かう形になることが推測される。先端載 荷方式（d）は，押込み試験の簡易化を目的として開発されたもの である2〉。これは杭先端部にジャッキを備え, ジャッキのストロー ク先端を杭先端とし，自杭の負の周面摩擦力を載荷反力として杭先 端地盤を押込むものである。この方式による荷重伝達線は，上記原 則に従って，杭先端から自杭周面に向かう形状になることが推測さ れる。地盤アンカー方式（e）は，反力梁に連結された地盤アンカ 一を載荷反力として杭頭載荷するものであり，荷重伝達線は，上記 原則に従って，杭周面および杭先端からアンカー抵抗体に向かい， 引張り材を通して反力梁に伝達されることが推測される。

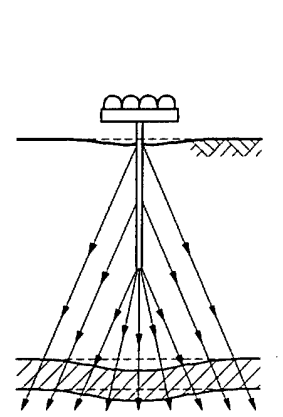

a.実載荷方式

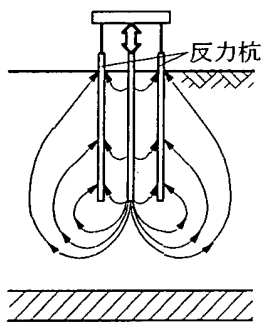

c.反力杭方式

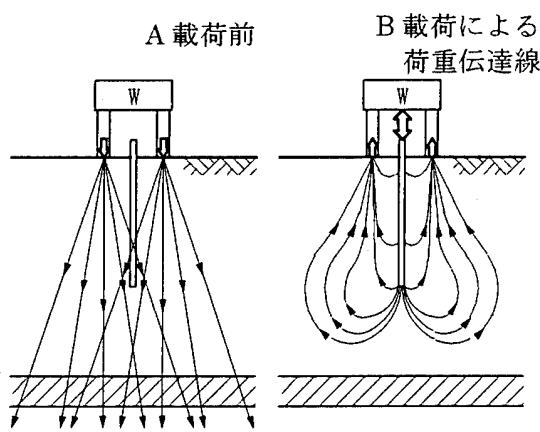

b.実重量反力方式

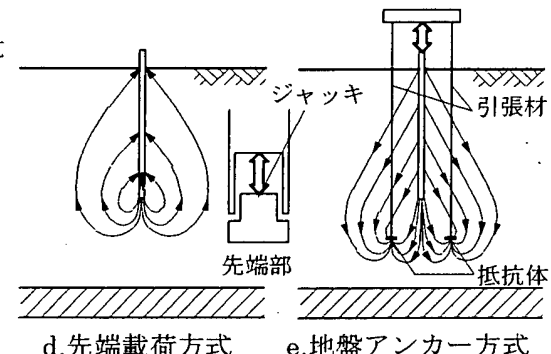

図 1 載荷原理と荷重伝達線の模式図

（2）押込み試験法の予想される問題点

載荷反力を用いた各種試験法（図 $1 \mathrm{~b} \sim \mathrm{e}$ ）の荷重伝達線は, 反 力方向に曲げられることが推測されるため, 実載荷方式（a）のも のとは地中の応力状態が異なったものになることが予想される。ま た，載荷による地盤変位と載荷反力による地盤変位は，互いに相殺 関倸にあるため，荷重〜沈下関倸への影響が想像される。

載荷反力による上記何れの方式も，実載荷方式との比較検討によ る研究は見当たらず，載荷反力による影響に関して不明な点が残さ れているものと思われる。ただし，先端載荷方式については，反力 杭方式を基準とした青木ら ${ }^{3)}$ ，岸田ら ${ }^{4)}$ ，小椋ら 5)の実大杭を用い た研究，杭周面摩擦力に着目した模型杭による吉村ら ${ }^{6)}$ の研究があ る。これらの研究によると, 先端載荷方式によって得られる結果は, 反力杭方式によるものよりも初期剛性を高く評価し，極限支持力を 低く評価する傾向にあることが報告されている。

\section{（3）本研究の概要}

模型杭に対しては, 荷重規模が小さいため実杭に対してはとんど 不可能とされていた実載荷試験が可能となる。模型試験は定量的な 把握が困難とされているが，ｉ）同一条件下での比較試験が可能で ある。ii）多数の試験をパラメトリックに行なえる。iii）少ない経 費で試験が出来る。などの長所を有しており，定性的な把握は可能 と思われる。

筆者らは，1998 年7)，8)において，模型杭に対して実載荷方式， 反力杭方式，先端載荷方式による押込み試験を行い，試験法の違い によって得られる支持力性状が異なることを把握した。また，その 影響因子が試験杭の周面摩擦力や載荷反力による先端地盤の鉛直拘 束圧一沈下関倸にあることを推察した。そして 1999 年 $\left.{ }^{9}\right) ， 2000$ 年 10)において，i）長方形土槽から円形土槽への改良，ii）杭先端と 土槽底間の距離の確保による土槽底剛境界の影響の低减化， iii）載 荷方法の改良，などを行い，模型杭に対する各種押込み方式（実載 荷方式, 反力杭方式, 先端載荷方式, 地盤アンカー方式）の試験を 行った。本論文は, 実載荷方式を基準とした各種試験法の比較検討 を行い，それぞれの荷重〜沈下特性について考察するものである。

\section{2. 試験概要および載荷方法}

\section{1 試験概要}

表 1 に試験一覧を示す。これらは長い模型杭を対象とし，先端部 分 $(288 \mathrm{~mm})$ を模型地盤に根入れさせ，模型地表面にはその上に 仮想される土被り圧 $\left(100 \mathrm{kN} / \mathrm{m}^{2}\right)$ を作用さている。

\begin{tabular}{|c|c|c|c|c|c|}
\hline 試験 & 載荷方式 & $\underset{\text { (mm) }}{\text { 杭径 D }}$ & 杭周面摩擦 & $\begin{array}{l}\text { 上載厓 } \\
\left(\mathrm{kN} / \mathrm{m}^{2}\right)\end{array}$ & $\begin{array}{c}\text { アンカー } \\
\text { 哚さ }\end{array}$ \\
\hline \multirow{3}{*}{ I } & \multirow{3}{*}{ 実載荷方式 } & 27 & \multirow{3}{*}{ 有り } & \multirow{3}{*}{100} & \multirow{9}{*}{-} \\
\hline & & 48 & & & \\
\hline & & 76 & & & \\
\hline \multirow{3}{*}{ II } & \multirow{3}{*}{ 実載荷方式 } & 27 & \multirow{3}{*}{ 無し } & \multirow{3}{*}{100} & \\
\hline & & 48 & & & \\
\hline & & 76 & & & \\
\hline III & 㥶載荷方式（擬似） & \multirow{3}{*}{48} & \multirow{3}{*}{ 有り } & $100+\Delta \sigma$ & \\
\hline IV & 反力杭方式(擬似) & & & $100-\Delta \sigma$ & \\
\hline $\mathrm{V}$ & 先端載荷方式（擬似） & & & $100-\Delta \sigma$ & \\
\hline \multirow{3}{*}{ VI } & \multirow{3}{*}{ 地盤アンカー方式 } & \multirow{3}{*}{48} & \multirow{3}{*}{ 有り } & \multirow{3}{*}{100} & $O D$ \\
\hline & & & & & 5D \\
\hline & & & & & $10 \mathrm{D}$ \\
\hline
\end{tabular}

ただし，試験 I は，土被り部分における杭の周面摩擦を排除した 部分フリクションカット杭 (図 9)，試験 I は杭全長にわたって周面 摩擦を排除した全フリクションカット杭に対する実載荷方式であり （図 10），これらは杭周面摩擦が杭先端支持力性状に与える影響を 調べることを目的としたものである。

試験而は土被り部分の杭の周面摩擦力による影響（杭先端近傍の 鉛直圧の増大）を加圧板一バネモデル（図 11）によって擬似的に再 現する実載荷方式，試験IVは土被り部分の反力杭（4本）门引抜き 抵抗力による影響（杭先端近傍の鈆直圧の減少）を反力体一バネモ デル（図 12）によって擬似的に再現する反力杭方式, 試験Vは，試 験 $\mathrm{V}$ と同一の反力体ーバネモデル（図 13）によって，土被り部分に 
おける自杭の負の摩擦力による影響（杭先端近傍の鉛直圧の減少） を擬似的に再現する先端載荷方式であり，これらの試験法の杭先端 支持力〜沈下曲線の定性的な把握を目的としている。

試験Vは，土被り部分の摩擦を排除した杭（試験 I と同一杭）に 対守る地盤アンカー万方式であり（図 14）, アンカー抵抗体の深さ（杭 先端からの媣さ)による影響を調べることを目的としたものである。 2.2 試験諸元

\section{(1) 実験装置}

図 2 に試験装置の全体概要を示す。試験土槽は直径 $1400 \mathrm{~mm}$, 高さ $1300 \mathrm{~mm}$ の鋼製円筒で，模型地表面に上載圧を作用させるこ とが可能な加圧室を有している。加圧の方法は, 模型地表面上に複 数の細長い空気袋を置き, 鋼製蓋と鋼製梁で抑え, 圧搾空気の送入 によって地表面を加圧する。

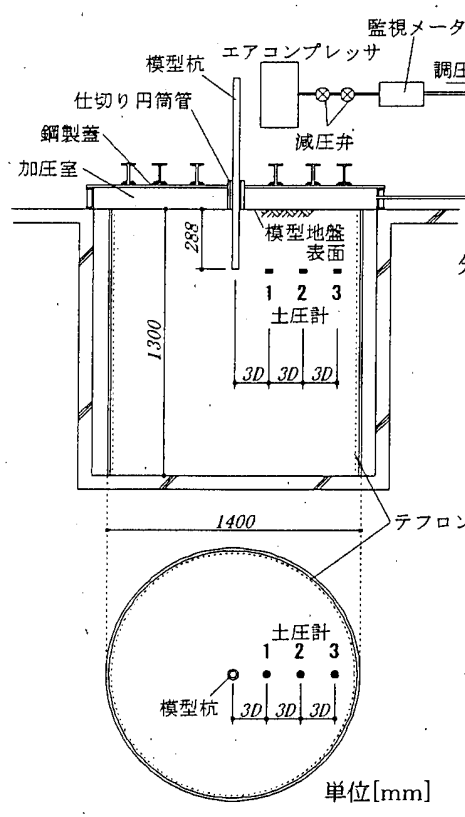

図 2 試験装置

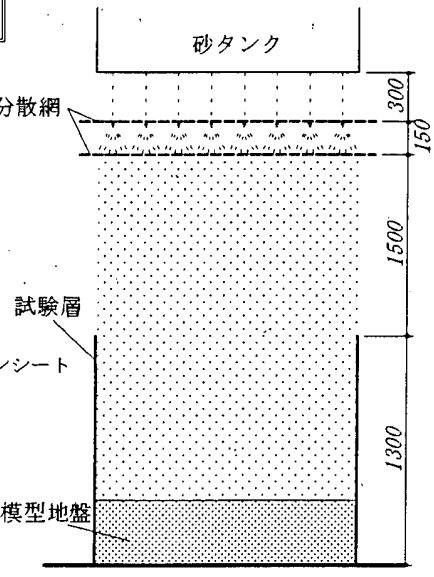

単位 $[\mathrm{mm}]$

図 3 砂詰め装置

\begin{tabular}{l|l}
\multicolumn{1}{c}{ 表 2} & \multicolumn{1}{c}{ 地盤諸元 } \\
\hline 使用砂 & 硅砂 5 号(砕砂) \\
\hline 産地 & 山形県飯豊 \\
\hline 土粒子密度 & $2.66 \mathrm{~g} / \mathrm{cm}^{3}$ \\
\hline 試験時密度 & $\begin{array}{l}1.76 \mathrm{~g} / \mathrm{cm}^{3} \\
\text { (気乾状態) }\end{array}$ \\
\hline 相対密度 & $95 \%$ \\
\hline 均等係数 & 2.1 \\
\hline
\end{tabular}

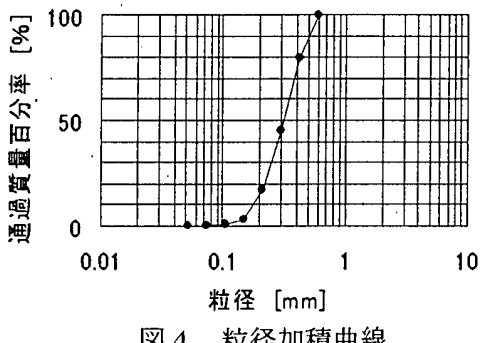

図 4 粒径加積曲線
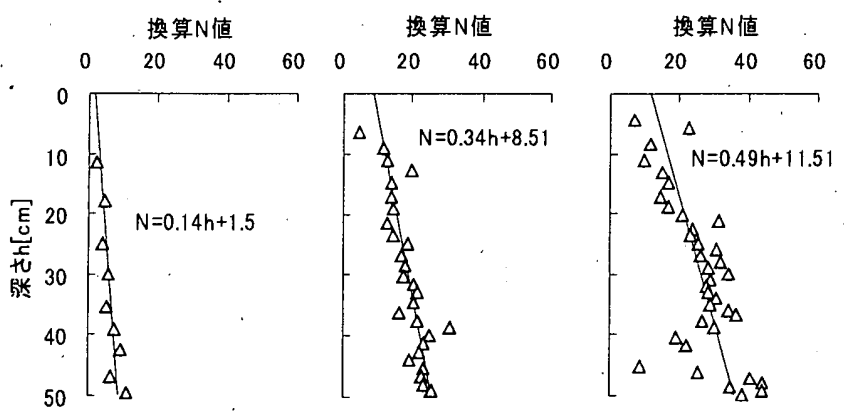

a. 上載圧 $0 \mathrm{kN} / \mathrm{m}^{2} \quad$ b. 上載圧 $50 \mathrm{kN} / \mathrm{m}^{2} \quad$ c. 上載圧 $100 \mathrm{kN} / \mathrm{m}^{2}$ 図 5 換算 $\mathrm{N}$ 值分布
表 3. 杭，仕切り円筒管寸法

\begin{tabular}{|c|c|c|c|c|c|}
\hline \multirow[b]{2}{*}{ 番号 } & \multicolumn{3}{|c|}{ 模型杭 } & \multicolumn{2}{|c|}{ 仕切り円筒管 } \\
\hline & $\begin{array}{l}\text { 外径 } \\
\text { [mm] }\end{array}$ & $\begin{array}{l}\text { 肉厚 } \\
{[\mathrm{mm}]}\end{array}$ & 杭周面の仕上げ & $\begin{array}{c}\text {. 外径 } \\
{[\mathrm{mm}]}\end{array}$ & $\begin{array}{l}\text { 肉厚 } \\
{[\mathrm{mm}]}\end{array}$ \\
\hline \multirow{3}{*}{ 試験 I } & 27 & \multirow{3}{*}{1.5 , } & \multirow{3}{*}{ ネジ(ピッチ $1 \mathrm{~mm})$} & 48 & 2.3 \\
\hline & 48 & & & 76 & 2.3 \\
\hline & 76 & & & 102 & 3.2 \\
\hline \multirow{3}{*}{ 試験 II } & 27 & \multirow{3}{*}{1.5} & \multirow{3}{*}{ テフロン2重 } & 48 & 2.3 \\
\hline & 48 & & & 76 & 2.3 \\
\hline & 76 & & & 102 & 3.2 \\
\hline 試験 III & 48 & 1.5 & ネジ(ピッチ $1 \mathrm{~mm})$ & 76 & 2.3 \\
\hline 試験 $\mathrm{V}$ & 48 & 1.5 & ネジ(ピッチ $1 \mathrm{~mm})$ & 76 & 2.3 \\
\hline \multirow{2}{*}{ 試験 V } & 48 (外杭) & 1.5 & ネジ(ピッチ $1 \mathrm{~mm})$ & \multirow{2}{*}{76} & \multirow{2}{*}{2.3} \\
\hline & 30. (中杭) & - & - & & \\
\hline \multirow{2}{*}{ 試験VI } & \multirow{2}{*}{48} & \multirow{2}{*}{1.5} & \multirow{2}{*}{ ネジ(ピッチ $1 \mathrm{~mm})$} & 76 (主杭) & \multirow{2}{*}{2.3} \\
\hline & & & & 27 (引張材) & \\
\hline
\end{tabular}

注）ネジ形式：三角ネジ

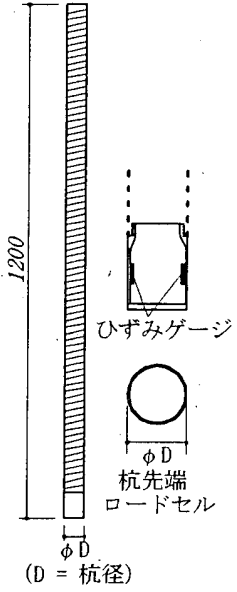

図 6 模型杭

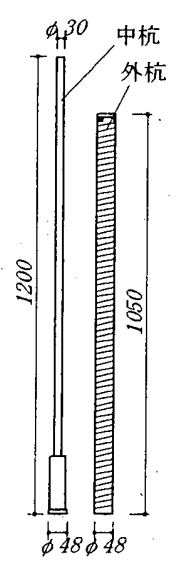

図 7. 先端載荷杭

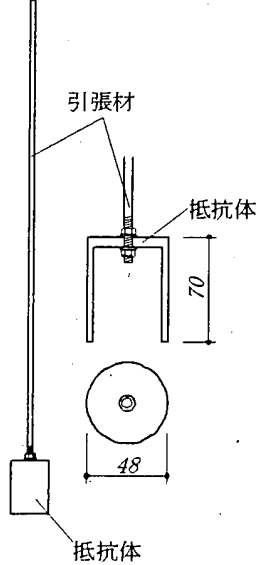

図 8 地盤アンカー
（2）砂詰め装置

実験土槽への砂詰めは，図 3 に示すような砂詰め装置を用いた。 本装置は, 砂タンク，砂を分散させる 2 枚の網を基本構成とし，砂 タンクの底には開閉が可能な砂落下孔（径 $6.0 \mathrm{~mm}$ ）が縦; 横 $20 \mathrm{~cm}$ 間隔で千鳥状に配列してある。また，分散網（網径 $2.0 \mathrm{~mm}$ ）は，砂 落下孔から下 $300 \mathrm{~mm}$ の位置に $150 \mathrm{~mm}$ の間隔で 2 枚が取り付けて ある。落下孔を開くと，各孔から筋を引いたように一斉に砂が落下 し， 2 枚の網で分散され, 試験土槽にほぼ一様に堆積する。なお, 試験土槽内の各場所で密度を測定した結果，それらがほぼ均一であ ることを確認している。

(3). 模型地盤

模型地盤には気乾状態の硅砂 5 号を用いた（表 2 ，図 4)。地盤作 成は, 最初に杭先端レベルまで砂詰めし，その上に杭体を置き，所 定の高さまで砂詰めした。図 5 に上載圧 $0,50,100 \mathrm{kN} / \mathrm{m}^{2}$ 下にお ける本地盤の換算N值を示す。なお，これらは同一地盤であっても 鉛直拘束圧によって換算 $\mathrm{N}$ 值が変化することを示している。ただし， 本換算 $\mathrm{N}$ 值は, 浅い模型地盤を対象としているため, 標準貫入試験 機による打撃貫入を地表面から所定の梁さまで連続して行い， 1 打 撃毎の沈下量から $30 \mathrm{~cm}$ 貫入に必要な打撃数を求めた（30 cm を一 打撃の貫入量で除した值)。上載圧 $100 \mathrm{kN} / \mathrm{m}^{2}$ の場合に見られる $\mathrm{N}$ 值 分布の乱れは， $0,50 \mathrm{kN} / \mathrm{m}^{2}$ においては大きな乱れが認められてい ないことから，砂詰めの不均一性によるものではなく，砂の不安定 さ（砂粒子の強度不足など）によるものと思われる。 
（4）模型杭，地盤アンカーおよび仕切り円筒管

模型杭（反力杭を含む）は鋼管を使用し，十分な摩擦力が得られ るように周面をネジ切り加工した（図6)。周面摩擦力の排除は，杭 周面にテフロン製シートを二重に巻き付ける方法で行なった。先端 載荷方式(試験 V) に用いる杭は二重管構造のものを用いた(図 7 )。 地盤アンカーは， $\phi 48 \mathrm{~mm}$, 高さ $70 \mathrm{~mm}$ の円筒形の支圧形抵抗体, 引張り材は $\phi 9 \mathrm{~mm}$ の $\mathrm{PC}$ 鋼棒を使用し,プレストレスの導入のない 待ち受け形式で使用した（図 8 )。なお，表 3 に杭，杭周面の仕上げ 状態および仕切り円筒管の寸法を示す。

（5）杭の荷重，沈下および地盤の鉛直圧の測定

杭の変位および杭頭荷重は，杭頭に設置したダイアルグージおよ びロードセルで測定した。杭先端荷重は杭先端部に装備したロード

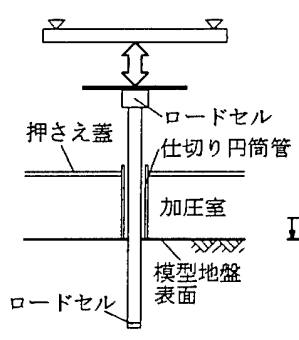

a . 載荷システム b . 模擬状態

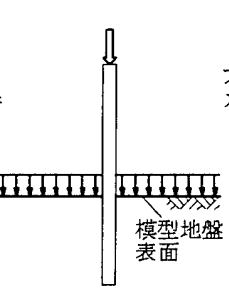

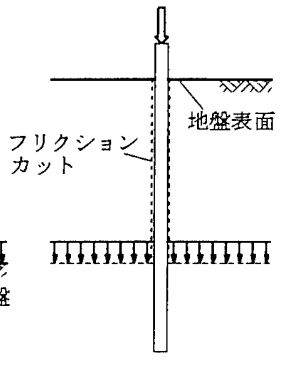

c . 実状態
図 9 試験 I （部分フリクションカット杭）
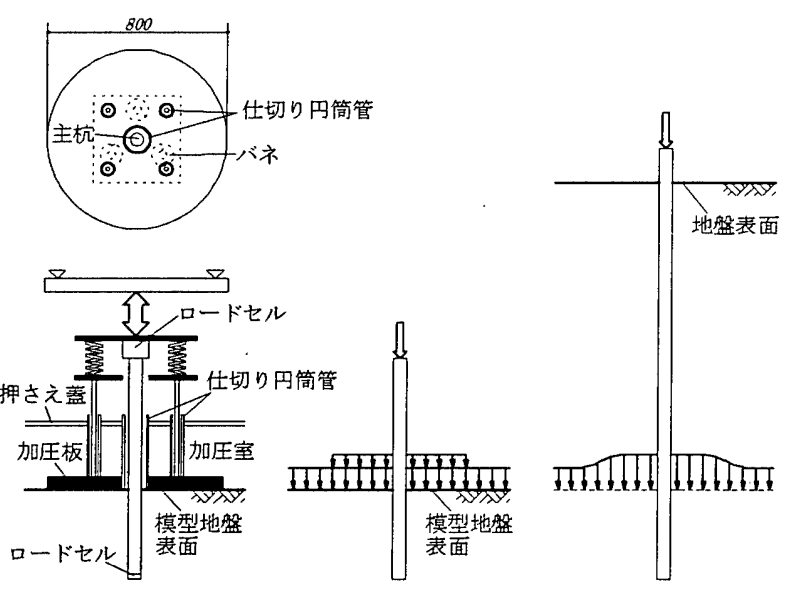

a . 載荷システム

b. 模擬状態

c. 実状態

図 11 試験 III（実載荷方式）
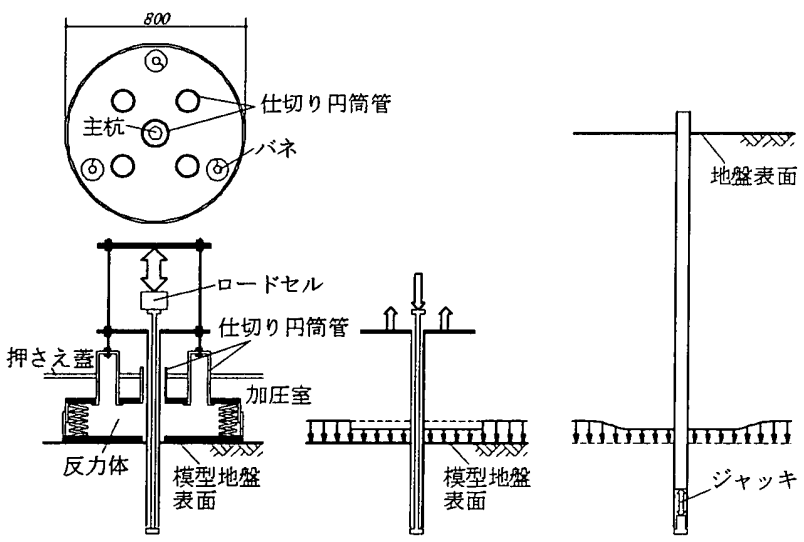
a ，載荷システム
b . 模擬状態
c . 実状態

図 13 試験 V（先端載荷方式）
セルで測定した（図 6)。ただし，先端載荷方式については，二重構 造の中杭頭部に設けたロードセルにより測定した。周面摩擦力は杭 頭荷重と杭先端荷重の差から求めた。なお，先端載荷方式の周面摩 擦力は杭先端荷重に一致するため, これを周面摩擦力とした。

また，杭先端から水平方向に $3 \mathrm{D} ， 6 \mathrm{D} ， 9 \mathrm{D}$ （D：杭径）の距離に 土压計を配置し，杭先端レベルでの鉛直圧を測定した（図 2 ）。 2.3 載荷装置および載荷システム

（1）試験 I および試験 II（実載荷方式）

試験Ｉおよび試験 II の載荷方法は，所定の仮想土被り圧（100 $\left.\mathrm{kN} / \mathrm{m}^{2}\right)$ を与えた後, 試験土槽の外に反力を設けた電動式の載荷装 置を用い, 杭頭に反力の影響の無い実荷重を直接的に与えた(図 9 , 図 10)。ただし, 試験杭は加圧室内の空気袋や押さえ蓋に接触しな
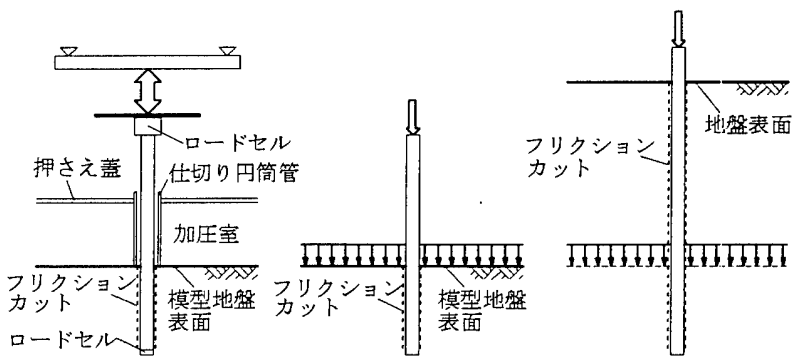
a. 載荷システム
b. 模擬状態
c. 実状態

図 10 試験III（全フリクションカット杭）

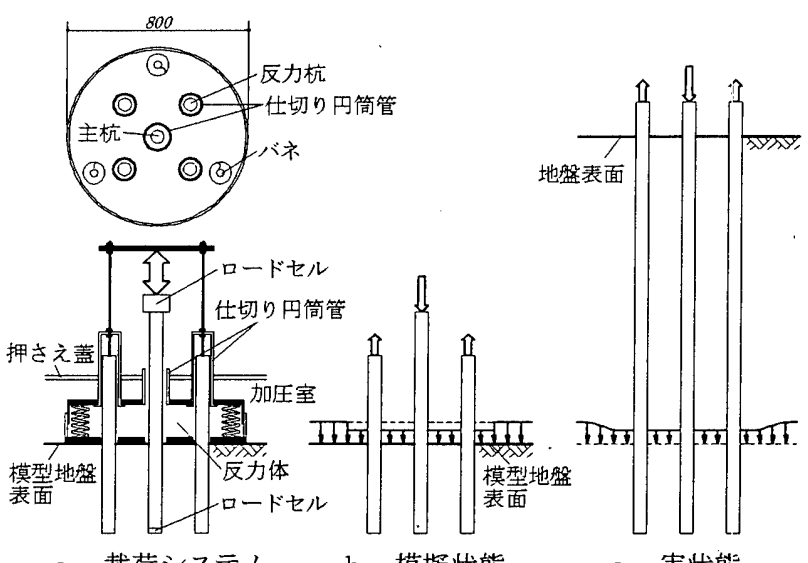
a . 載荷システム
b . 模擬状態
c . 実状態

図 12 試験IV（反力杭方式）

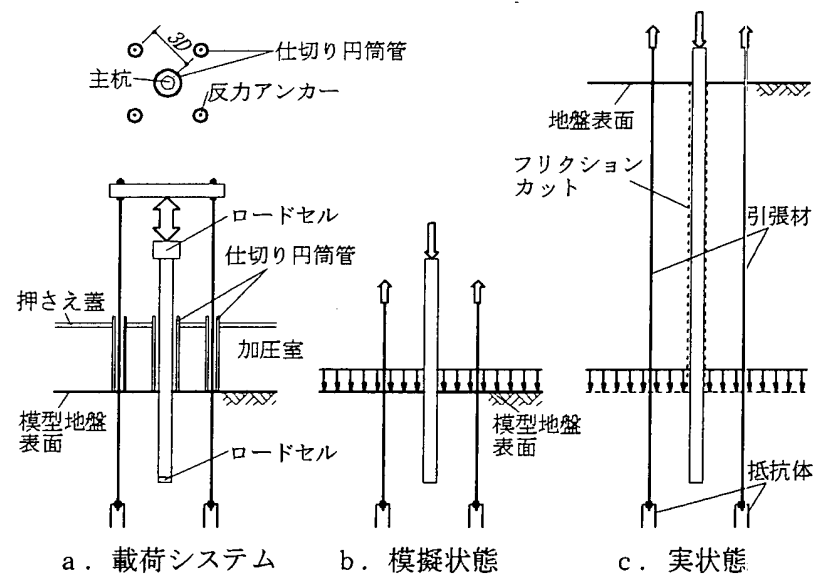

図 14 試験 VI（地盤アンカー方式） 
いように，薄肉鋼管製の仕切り円筒管（表 3）で保護している。

（2）試験III（実載荷方式）

試験IIIの載荷方法は, 図 11 に示すような加圧板（径 $800 \mathrm{~mm}$ ), 加圧室を貫く 4 本の柱を持つ台座， 3 個のつる巻きバネ(総バネ係 数 $3.0 \mathrm{kN} / \mathrm{mm}$, 弾性限界時の圧縮量 $20 \mathrm{~mm}$ ) から構成した加圧板 一バネモデルを使用する。載荷システムは, 所定の圧力（仮想土被 り圧 $\left.100 \mathrm{kN} / \mathrm{m}^{2}\right)$ で模型地表面を加圧した後，バネ上端と杭頭が同 一高さとなるように調整し，その上に載荷板を置き，バネと杭頭を 同時に押込むことによって，杭頭載荷と杭近傍における模型地表面 の鉛直圧の増大を同時に行うものである。ただし，この鉛直圧の増 分は, 杭頭沈下量と模型地表面の沈下量の差にバネ係数 (3.0 $\mathrm{kN} / \mathrm{mm})$ を乗じ, これを加圧板面積 $\left(0.50 \mathrm{~m}^{2}\right)$ で除した值となる。

（3）試験IV（反力杭方式）

試験 $\mathrm{V}$ の載荷装置は, 図 12 に示すような嵌合する上下 2 つの円形 箱（径 $800 \mathrm{~mm}$ ）内に 3 個のつる巻きバネ（試験而に同じ）を内藏 させた反力体ーバネモデルを使用する。試験杭および反力杭 (4 本) は仕切り円筒管（表 3) で保護しており, 反力杭用の仕切り円筒管 は反力体の上箱に結合させている。載荷システムは, 模型地表面に 所定の仮想土被り圧 $\left(100 \mathrm{kN} / \mathrm{m}^{2}\right)$ を与え, 反カ体がプレストレス 状態となった後, 反力杭頭部と反力杭用仕切り円筒管の頭部とを厚 鋼板で結合し，これを反力として杭頭をジャッキで押込むものであ る。載荷に伴うて反力体のプレストレス量が減少し, 反力体底面下 の接地圧が低下する。この模型地表面における鉛直圧の減少量は, 杭頭荷重（二仕切り円筒管頭部の引張り力）から反力杭（4本）の 地中部の引抜き抵抗力を差し引き，これを反力体底面積 $\left(0.50 \mathrm{~m}^{2}\right)$ で除した値となる。

\section{（4）試験 V（先端載荷方式）}

試験 $\mathrm{V}$ の載荷装置は, 試験 $\mathrm{V}$ と同一の反力体一バネモデルを使用 する。載荷システムは, 地表面の加圧によって反力体をプレストレ ス状態 $\left(100 \mathrm{kN} / \mathrm{m}^{2}\right)$ とした後, 杭外管と反力体が一体となって抵 抗するように, 外杭と 4 本の仕切り円筒管頭部とを厚鋼板で結合し, これを反カとして中杭頭部をオイルジャッキで押込むものである (図 13)。載荷によって反力体のプレストレス量が減少し, 反力体 底面下の接地圧が低下寸る。この模型地表面における鉛直拘束圧の 减少量は, 杭先端荷重（ジャッキ荷重）から自杭地中部の引抜き抵 抗力を差し引き,これを反力体底面積 $\left(0.50 \mathrm{~m}^{2}\right)$ で除した值となる。

（5）試験VI（地盤アンカー方式）

試験VIは，待ち受け形式の地盤アンカー 4 本を用いる（図 14）。 載荷は, 模型地表面に所定の仮想土被り圧 $\left(100 \mathrm{kN} / \mathrm{m}^{2}\right)$ を与えた 後, 广ンカー引張り材頭部を反力板に連結し, これを反力として杭 頭をオイルジャッキで押込むものである。

\section{3. 試験結果の考察}

本試験の全ての杭先端荷重〜沈下関倸（R- $\delta$ 曲線）および土圧 計 $1,2,3$ の土庄変動量〜沈下関係 $(\Delta \sigma-\delta$ 曲線) を, 文末に 試験結果一覧として示してある。

\section{1 杭周面摩擦力の影響（試験 I および試験 II)}

図 15 は，試験 I（部分フリクションカット杭）および試験 I（全 フリクションカット杭）の杭先端荷重〜沈下関係の杭径別による比 較である。これらの曲線の立ち上がり勾配（初期剛性）は，何れも

試験 II の方が試験 I よりも大きくなっている：また，沈下がある大 きさ以上になると，これらの杭先端荷重の関係は，試験 I の方が試 験 II よりも大きくなる傾向が認められ，曲線形状の推測から，試験 I の杭先端極限荷重は試験 Iよりも大きくなることが推察される。

これらは以下のように説明される。

(1) 杭先端近傍の鉛直圧

杭周面摩擦を有寸る杭の杭頭荷重は, 杭周面摩擦力および杭先端 荷重として地中に伝達され，杭先端レベルにおける杭近傍の鉛直圧 は，杭周面摩擦力によって増大することが予想される。図 16 は杭 先端レベルの土圧計 1 (図 2). の土圧変動量〜沈下関係を示したも のであるが，何れの杭においても試験 I の鉛直圧は試験 Iよりも大 きくなっており，杭先端近傍の鉛直圧は上部杭の周面摩擦力によっ て増大することを検証している。

(2) 杭先端荷重の初期䣓性

杭周面摩擦を有する杭の荷重初期における杭頭荷重は, 主に杭周 面摩擦力によって支持され, その残りが杭先端へ伝達されるため, 初期荷重時における沈下は, 主に杭周面摩擦力による鉛直圧によっ て引き起こされることになる。また，杭周面摩擦力が大きなものほ ど，それによる沈下が大きく，杭先端に伝達される荷重値が低くな

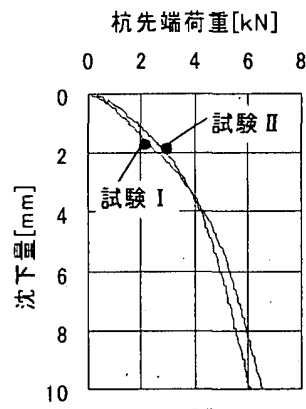

a. $\phi 27$

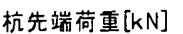

杭先端荷重 [kN] $\begin{array}{lllllllll}0 & 5 & 10 & 15 & 20 & 0 & 10 & 20 & 30\end{array}$

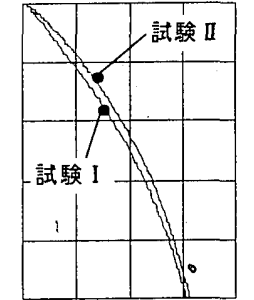

b. $\phi 48$

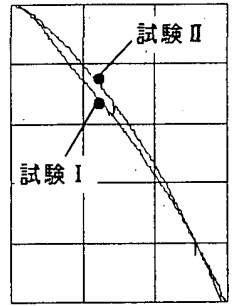

c. $\phi 76$
図 15 試験 $\mathrm{I}$, II $の \mathrm{R}-\delta$ 曲線の比較

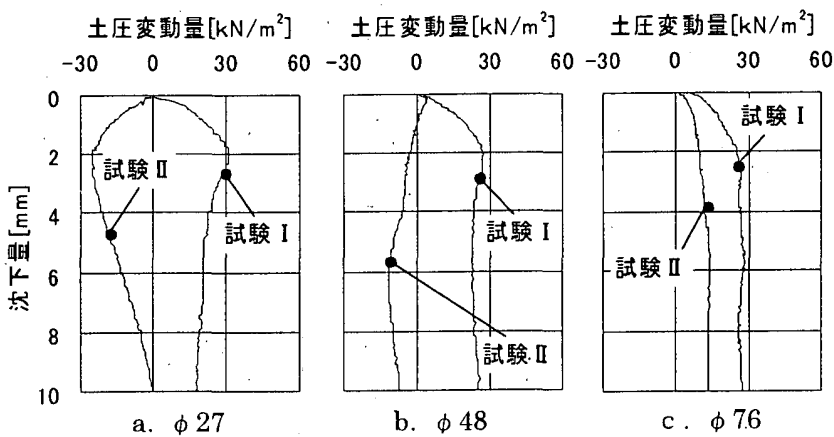

図 16 試験 I， 【の $\Delta \sigma-\delta$ 曲線の比較
$\mathrm{R} / \mathrm{R}_{0.1}$

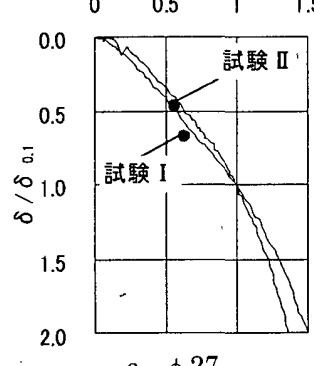

a. $\phi 27$
$\mathrm{R} / \mathrm{R}_{0.1}$

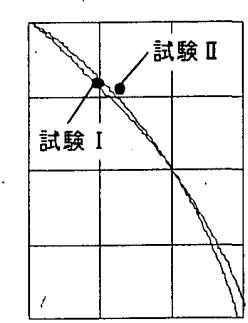

b. $\phi 48$
$\mathrm{R} / \mathrm{R}_{0.1}$

$\begin{array}{lllll}5 & 0 & 0.5 & 1 & 1.5\end{array}$

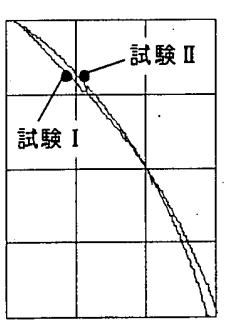

c. $\phi 76$
図 17 試験 $\mathrm{I} ， \mathrm{II} の \mathrm{R} / \mathrm{R}_{01}-\delta / \delta_{01}$ 曲線の比較 
ることが考えられる。即ち，杭周面摩擦を有する杭の方が杭周面摩 擦を排除した杭よりも，初期剛性が低くなることが推察される。

\section{(3) 杭先端極限荷重}

沈下が進み, 杭周面摩擦抵抗力の増大傾向が低下すると, 杭先端 一伝達される荷重が增大し, やがて極限状態に至る。この過程にお いて，杭周面摩擦力が大きなものほど，杭先端地盤に㳔する鉛直圧 が大きくなり，その鉛直拘束圧によって杭先端地盤の強度が増大寸 ることになる。したがって，ある沈下量になると，荷重初期の杭先 端荷重の関係が逆転し, 杭周面摩擦を有する杭の方が, 杭周面摩擦 の無い杭よりも杭先端荷重が大きくなることが推測される。また, 極限状態において, 杭周面摩擦を有する杭の方が, 杭周面摩擦の無 い杭よりも杭先端極限支持力が大きくなることが推測される。

(4) $\mathrm{R} / \mathrm{R}_{0.1}-\delta / \delta_{0.1}$ 曲線

図 17 は, $\mathrm{R}-\delta$ 曲線（杭先端荷重～沈下曲線）を，綎軸に $0.1 \mathrm{D}$ 時沈下量 $\left(\delta_{0.1}\right)$ を基淮とした無次元沈下量 $\left(\delta / \delta_{0.1}\right)$, 横軸に 0.1 $\mathrm{D}$ 沈下時の杭先端荷重值 $\left(\mathrm{R}_{0.1}\right)$ を基準とした無次元荷重値 $\left(\mathrm{R} / \mathrm{R}_{0.1}\right)$ として表したものである。これらは $\delta / \delta 0.1<1$ において試験 I の方 が試験 I よりも外側に膨らんだ曲線形状を示しており，杭周面摩擦 力の影響（杭先端近傍の鉛直圧の增大）が明確に現れている。

\section{2 試験法の比較検討}

\section{（1）実載荷方式，反力杭方式と先端載荷方式の比較検討}

図 18 に試験 $\mathrm{III} \sim$ 試験 $\mathrm{V}$ の杭先端荷重〜沈下関係を示寸。実載荷 方式の初期時における杭先端荷重は反力杭方式および先端載荷方式 よりも低く，沈下がある程度進んだ時点から，実載荷方式の方がそ れらよりも大きくなっている。また，実載荷方式の曲線の形状は， 反力杭方式および先端載荷方式よりも初期剛性が小さく，それらよ りも杭先端極限荷重が大きくなることが推察される $\mathrm{S}$ 宇形曲線を示 している。

これらは以下のように説明される。

(1) 杭先端荷重の初期剛性

載荷反力による地盤変位は，載荷による地盤沈下を相殺する方向 に働く。したがって，反力杭方式および先端載荷方式による杭の沈 下は, 反力の影響の無い実載荷方式よりも小さく評価され，初期剛 性は高く評価されることになる。

(2) 杭先端極限荷重

実載荷方式において，沈下がある大きさ以上になると，杭周面摩 擦抵抗力の増加傾向が低下し，杭先端に十分な荷重が伝達されるよ うになることは，試験 I と同様である。杭先端地船の支持力が鉛直 拘束圧に支配されることを考えると，杭周面摩擦力が鉛直拘束圧と して働く実載荷方式の方が，反力によって鉛直圧が堿少する載荷反 力による方式（試験 $\mathrm{V}$ ，試験 V) よりも杭先端極限荷重が大きくな ることが推察される。なお，図 19 に示した杭先端レベルの土圧計 1 （図 2）の土圧変動量～沈下関係を見ると，赛載荷方式の土圧変 動量は増大しているのに対し，反力杭方式および先端載荷方式は減 少しており，上記，鉛直拘束圧の考察に対応している。

（2）反力杭方式と先端載荷方式の比較検討

反力杭方式（試験IV）と先端載荷方式（試験 V) の，杭および模型 地表面の加圧システムは同様な条件下にあり，量的な比較検討が可 能である。これらの比較において（図 18），沈下が大きくなると， 杭先端荷重は反力杭方式の方が先端載荷方式よりも大きくなってい
る。また，曲線の性状から推測して，反力杭方式における杭先端極 限荷重は先端載荷方式よりも大きくなることが推察される。これは 既往の研究3) 6) と同様な結果である。またこれは，図 19 におい て反力杭方式（試験IV）の土圧変動量は先端載荷方式よりも大きな 值を示しており，杭先端極限支持力は，反力杭方式の方が先端載荷 方式よりも大きくなることに対応している。

（3）実載荷方式と地盤アンカー方式の比較検討

図 20 は，実載荷方式（試験 I）と地盤アンカー方式（試験 VI） の杭先端荷重〜沈下関係を示したものである。これらは，抵抗体の 杭先端からの梁さが杭径の 5 倍以上になると実載荷方式のものに漸 近している。図 21 は杭先端レベルの土圧計 1 (図 2) の土圧変動 量〜沈下関係を示したものである。これらも同様に、抵抗体の哚さ が杭径の 5 倍以上になると実載荷方式のものに漸近している。これ はアンカー梁さが増大寸ると, 荷重伝達線が地中染くまで広がり, 支持力性状に影響する領域での荷重伝達線が実載荷方式のものに近
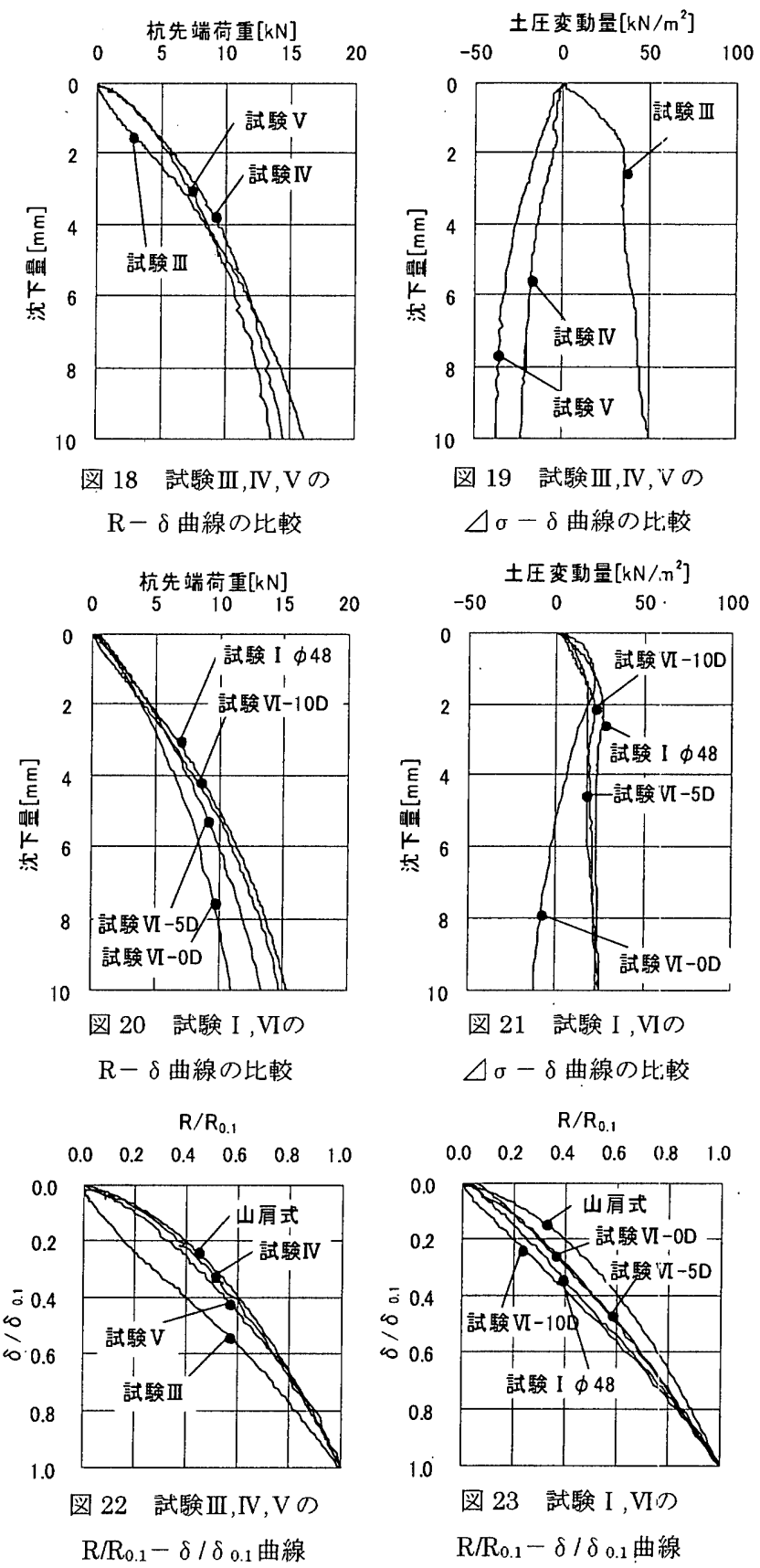

$\begin{array}{llllll}0.0 & 0.2 & 0.4 & 0.6 & 0.8 & 1.0\end{array}$

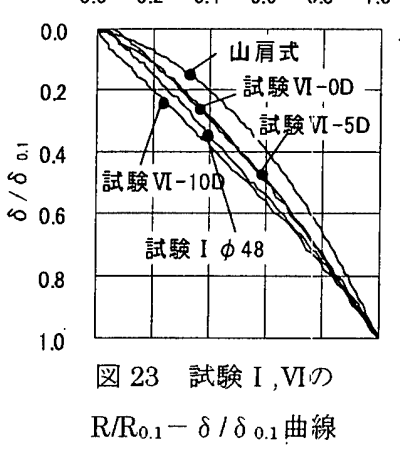


づくためと推測される(図1 aおよび図 1 e 参照)。

（4）杭先端荷重～沈下曲線の性質

図 22 は反力杭方式 (試験 $I V$ ) 上先端載荷方式（試験 V)，図 23 は地盤アンカー方式（試験 VI）の杭先端荷重〜沈下無次元曲線 $\left(\mathrm{R} / \mathrm{R}_{0.1}-\delta / \delta_{0.1}\right.$ 曲線) である。図 22 には試験 III'(実載荷方式)上 山有の曲線式 11 )が，図 23 には試験 I (実載荷方式) と山肩の曲線 式が記載してある。ただし, 図 23 において, 試験 $\mathrm{VI}-0 \mathrm{D}$, 試験 $\mathrm{VI}$ $-5 \mathrm{D}$ および試験 I $-48 \phi$ の各曲線の出発点が原点から若干離れて いることが認められるが，これは載荷前の準備段階で，何らかの原 因で杭頭に荷重を加えてしまい，その除荷の状態をゼ口状態として 測定したことによる荷重履歴の影響（再荷重による高剖性）が現れ たものと思われる。

これらを見ると, 反力杭方式と先端載荷方式のものは膨らみのあ る山肩式の曲線に近似している。これに対して実载荷方式および地 盤アンカー方式による曲線は直線的なものとなっている。山同の曲 線式は, 載荷反力を用いた載荷試験結果から導いたことを考えると， 本反力杭方式が山肩の曲線に近似することは当然の結果と判断され る。

なお，無次元曲線（図 22，23）の形状は, 曲率が最大となる点が， $\delta / \mathrm{D}>0.1$ か $\delta / \mathrm{D}<0.1$ かに支配され，前者ならばより直線的であり， 後者ならばより膨らみのある曲線になる。したがって, 曲率が最大 となる沈下量は, 実載荷方式の方が載荷反力を用いたものよりも大 きくなることが推察され，より直線的な形状を示す実載荷方式の最 大曲率の位置は $\delta / D>0.1$ であることが推察される。

\section{4. 結 論}

模型杭による実載荷方式および載荷反力を用いた各種押込み試験 を実施し，以下のことが考察された。

(1) 実載荷方式による杭周面摩擦力の影響

杭周面摩擦を有する杭の杭先端荷重〜沈下関係において, 初期䒽 性は，杭周面摩擦を排除した杭よりも低く評価され，杭先端極限 支持力は，杭周面摩擦力を排除した杭よりも大きく評価される。

(2) 反力杭方式による杭先端荷重〜沈下関倸

反力杭方式によって求められる杭先端荷重～沈下関係において， 初期腩性は，実載荷方式よりも高く評価され，杭先端極限支持力 は低く評価される。

(3) 先端載荷方式による先端荷重〜沈下関係

先端載荷方式によって求められる杭先端荷重一沈下関係において, 初期㓮性は，実載荷方式によって求められるものよりも高く評価 され，杭先端極限支持力は実載荷方式および反力杭方式よりも低 く評価される。

(4) 地盤アンカー方式による杭先端荷重〜沈下関倸

地盤アンカー方式において引抜き抵抗体を杭先端下の深い所（本 模型実験では杭径の 5 倍程度以上）に置くと，実載荷方式のもの に近似した杭先端荷重〜沈下関係が得られる。

(5) 杭先端荷重〜沈下曲線の形状.

実載荷方式における杭先端荷重〜沈下曲線は, 反力杭方式や先端 載荷方式よりも，初期剛性が低く，杭先端極限支持力が大きい $\mathrm{S}$ 字形曲線を呈する。
(6) $\mathrm{R} / \mathrm{R}_{0.1}-\delta / \delta_{0.1}$ 曲線の形状

杭先端荷重～沈下無次元曲線（R/R $R_{0.1}-\delta / \delta 0.1$ 曲線）において， 実載荷方式は, 直線に近い曲線を示すのに対し, 反力杭方式およ び先端載荷方式のものは膨らみのある曲線を呈する。

(総 括)

模型杭を用いることにより，実大杭に対して困難であった害載荷 方式による試験が可能となった。しかし, 載荷反力による試験は, 同一土槽内に反力体を設置寸る必要があり, 実載荷方式よりも難し い試験となった。

模型試験であるため，定量的な把握が出来なかったが，各種押し 込み試験法によっての特性が理解された。特に, 地盤アンカー方式 が，実大杭に対する実載荷方式に近似した結果を得る一つの実施可 能な方法になり得ることが解った。この方法を含め, 実大杭に対す る荷重〜沈下関保を推測する方法を見出すこ上は, 今後の大きな課 題になるもの上思われる。

本試験における沈下の測定は, 実験土槽外の絶対的不動点を基準 として測定したが，実試験における測定は，杭近傍を不動点とする 相対沈下を測定しており，不動点に対する載荷反力による影響が無 視されている。これを考慮すると，さらに新しい見解が生まれるこ とが想像される。これも今後の大きな研究課題として残されている ものと思われる。

\section{謝 辞}

最後に，本試験は東京電力（株）の協力により行ないました。実 験等は当時大学院生であった唐鎌成夫氏，佐藤有伸氏，成山嶺高氏 の修士論文として行なったものであることを申し添えておきます。

[参考文献]

1）地盤工学会基準，杭の鉛直载荷試験法・同解説 第一回改訂版, 2002 2）藤岡豊一,新井邦夫,新井厚生,山田清臣：新しい杭の鉛直載荷試験法の 開発，土と基㲥，Vol.39，No.4，pp.27～32，1991.

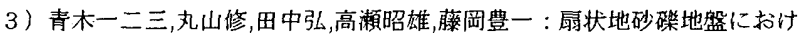
る場所打ち杭の鉛直載荷試験（その 2 : 載荷試験結果），士木学会第 47 回 年次学術满演会梗概集 第3 部, pp.868 869, 1992

4）岸田英明,桑原文夫,鉿木俊雄,川村浩,小椋仁志,須見光二：OAP 計画に お汸杭の支持力実験(その $4:$ 先端抵抗と摩擦抵抗の検討), 日本建築学会 学術踡演梗概集(北陸),Vol.B-1,pp1263〜1264,1992

5 ）小椋仁志,須見光二,岸田英明,吉福司：杭先端載荷試験法の場所打ち杭 と既製杭一の適用，士と基礎，Vol.43,No. 5,pp.31 33,1995 6) 吉村啓太,传々木隆光,末政直晃,片田敏行,吉田茂: 杭の周面摩擦の作用 方向が先端荷重〜沈下特性に及ほす影響, 第 36 回地盤工学研究発表会, pp. 1595 1596,2001

7 ）国府田諴，山下利夫，田村昌仁，传藤秀人，唐鎌成夫，传藤有伸，他：模型杭 による鉛直輔荷試験法の㛟郡 その $1 \sim$ その, 第 33 回地盤工学研究発表 会(山口),pp1429〜 1434,1998

8) 国府田誠, 山下利夫,田村昌仁,传藤秀人,唐鎌成夫,佐藤有伸,他: 模型杭 による鈆直載荷試験 その 1 その 2 , 日本建築学会学術講演梗概集(福 岡), VolB-1,pp663 666,1998

9）国府田誠，山下利夫，田村昌仁，晟藤英明，佐藤秀人,笹沼美和,成山嶺高, 他: 模型杭による各種载荷試験とその考察 その 1 その 3 , 日本建築学会 学術講演梗概集(中国)，Vol.B-1，pp679～684,1999

10）国腑田誠,山下利夫,田村昌仁, 齐藤英明,佐藤秀人, 笹沼美和, 他: 模型杭 による杭の鉛直載荷試験法に関する研究 その 1 その 2 , 第 35 回地盤工 学研究発表会(岐阜), pp 11 14，2000

11）山肩邦男,伊藤潡志,山田毅, 田中健 : 場所打ちコンクリート杭の極限先 端荷重および先端荷重〜先端沈下量特性に関する統計的研究，日本建筑学 会構造系論文報告集，No.423，pp137～146，1991.5 
[試験結果一覧]

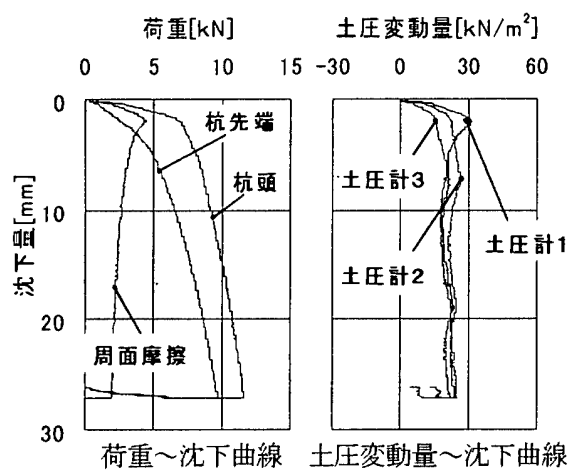

a. $\phi 27 \mathrm{~mm}$

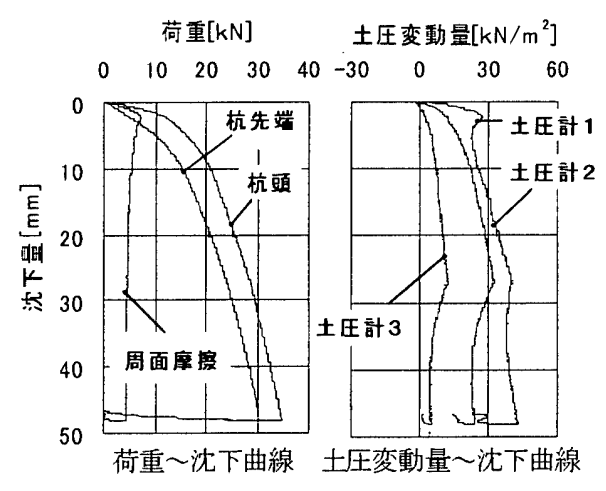

b. $\phi 48 \mathrm{~mm}$

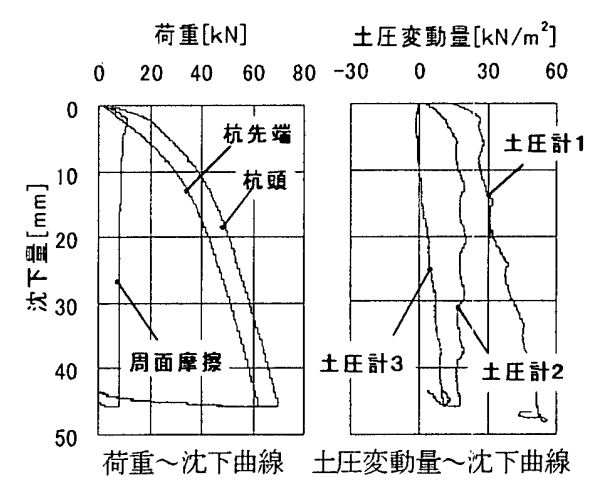

c. $\phi 76 \mathrm{~mm}$

付図 1 試験 I （実載荷方式: 部分フリクションカット杭）

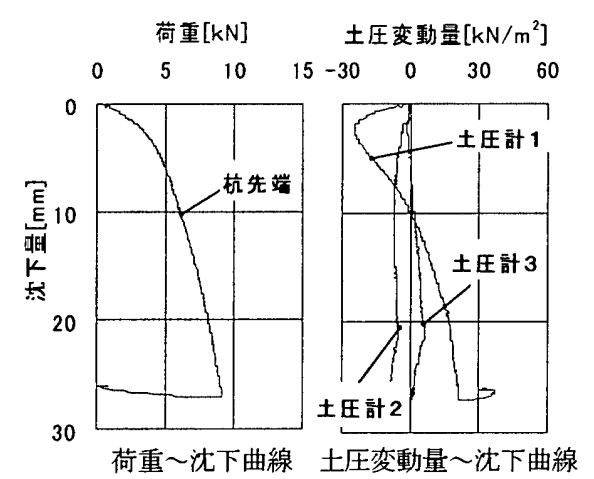

a. $\phi 27 \mathrm{~mm}$

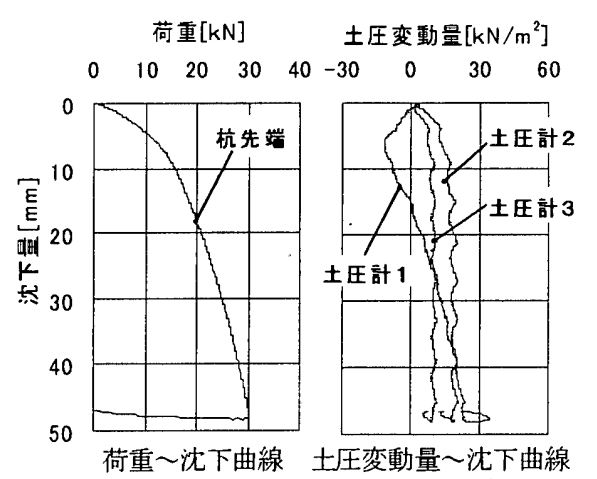

b. $\phi 48 \mathrm{~mm}$

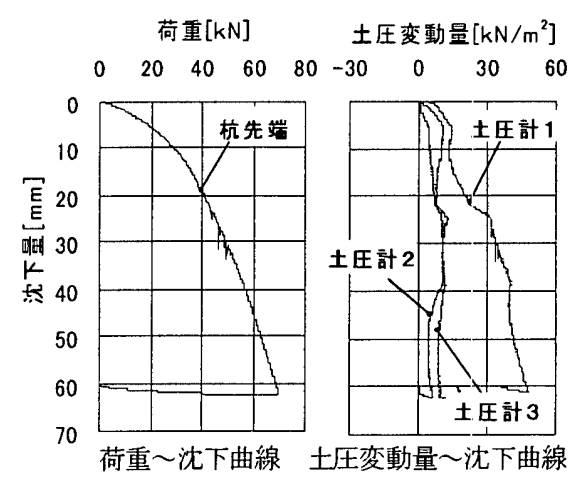

c. $\phi 76 \mathrm{~mm}$

付図 2 試験 II（実載荷方式 : 全フリクションカット杭）
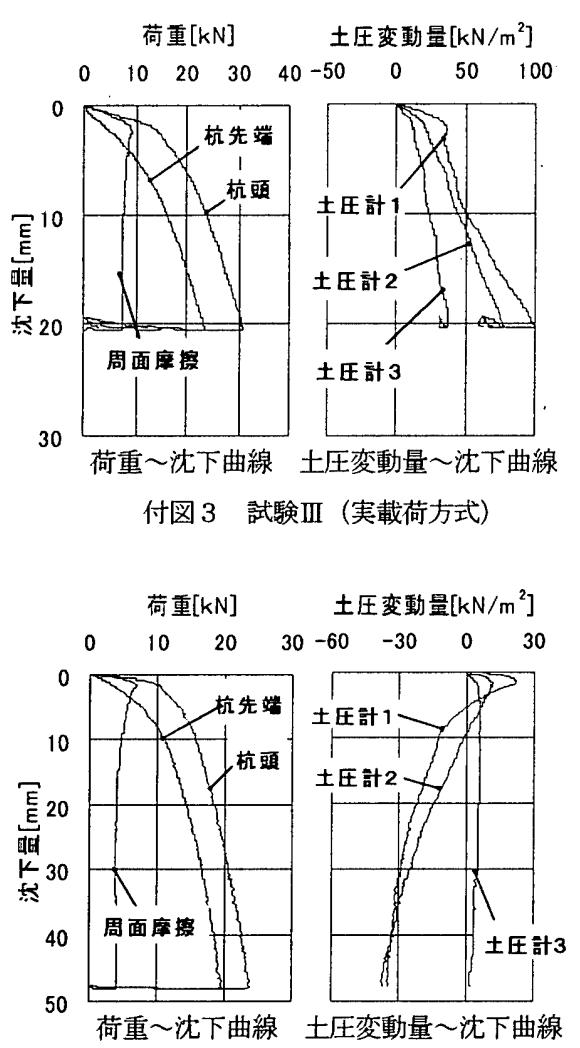

a. 設置深さ* : OD
荷重 $[\mathrm{kN}]$ 土圧变動量 $\left[\mathrm{kN} / \mathrm{m}^{2}\right]$

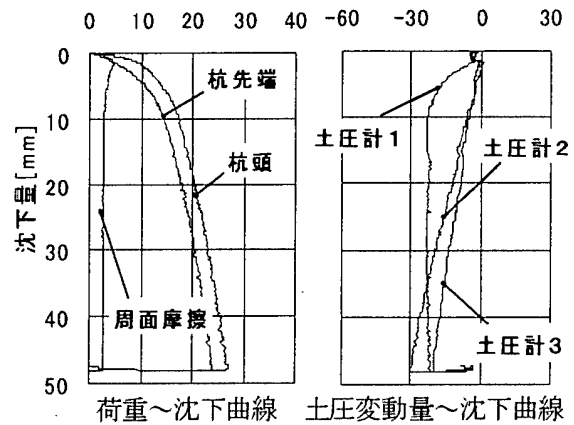

付図 4 試験IV（反力杭方式）

荷重 $[\mathrm{kN}]$ 土压变動量 $\left[\mathrm{kN} / \mathrm{m}^{2}\right]$ $\begin{array}{lllllllll}0 & 10 & 20 & 30 & 40 & -30 & 0 & 30 & 60\end{array}$

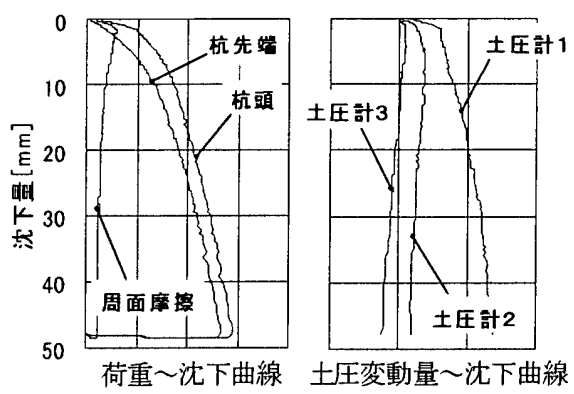
b. 設置深さ※ : $5 \mathrm{D}$

付図 6 試験VI（地盤アンカー方式）

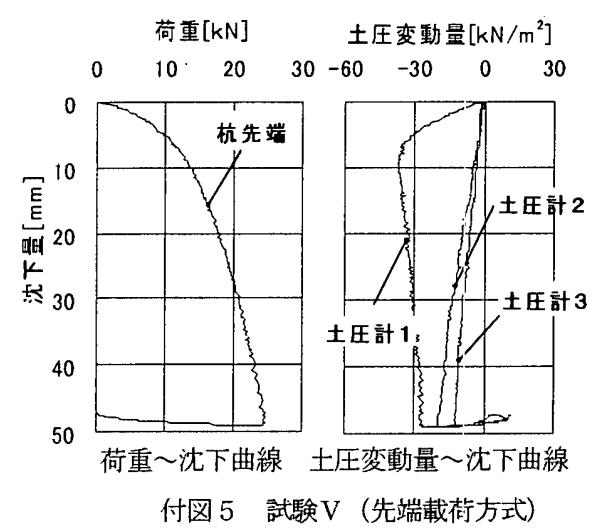

荷重 $[k N]$ 土圧变動量 $\left[k \mathrm{~N} / \mathrm{m}^{2}\right]$ $\begin{array}{lllllllll}0 & 10 & 20 & 30 & 40 & -30 & 0 & 30 & 60\end{array}$

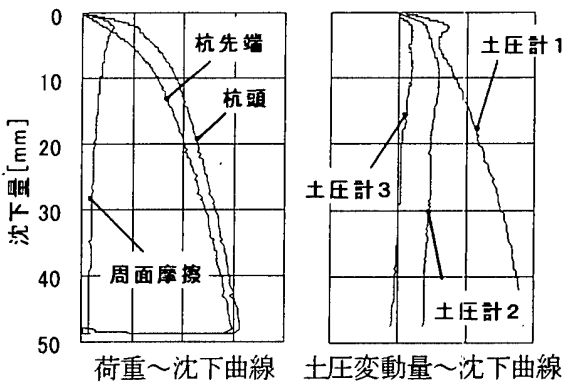

c. 設置媣さ ${ }^{*}: 10 \mathrm{D}$ ※ 設置深さは杭先端からの深さ

（2002年 7 月 10 日原稿受理， 2003 年 1 月 9 日採用決定） 